\title{
Sosialisasi dan Edukasi Pemanfaatan Tanaman Berkhasiat Obat Dalam Menghadapi Masa Pandemi COVID-19 di Kota Kendari
}

\author{
Ruslin, La Ode Muhammad Fitrawan, Asniar Pascayantri, Andi Nafisah Tendri Adjeng* \\ Department of Pharmacy, Faculty of Pharmacy, Universitas Halu Oleo, Jl. HEA. Mokodompit, Anduonohu, \\ Kendari-South East Sulawesi, Indonesia, 93232
}

\begin{abstract}
ABSTRAK
Coronavirus-19 (COVID) telah dinyatakan sebagai pandemi dunia oleh WHO. Virus dan penyakit ini diketahui berawal di kota Wuhan, Cina sejak Desember 2019. Presiden Republik Indonesia telah menyatakan status penyakit ini menjadi tahap Tanggap Darurat pada Maret 2020. Dalam rangka penanganan cepat COVID-19 diperlukan pemahaman masyarakat mengenai tindakan pencegahan untuk Kesehatan Masyarakat COVID-19 di Indonesia khususnya di beberapa daerah Kota Kendari yaitu kelurahan Pondambea dan Anduonohu. Tujuan Pengabdian Kepada Masyarakat (PKM) Internal Universitas Halu Oleo kepada masyarakat adalah membantu pemerintah setempat dalam meningkatkan kesadaran masyarakat untuk mencegah dan melawan virus covid-19 dalam bentuk pemanfaatan tanaman berkhasiat yang dapat meningkatkan sistem imunitas tubuh. Bentuk kegiatan pengabdian kepada masyarakat yaitu memberi penyuluhan yaitu metode ceramah dan tanya jawab secara door to door dan pembagian leaflet serta masker gratis, luaran yang dihasilkan yaitu peningkatan pemahaman dan keterampilan masyarakat dalam mengolah dan memanfaatkan tanaman berkhasiat obat sehingga dicapai peningkatan ketentraman/kesehatan masyarakat (mitra masyarakat umum).
\end{abstract}

Kata kunci: COVID-19; Kota Kendari; Sosialisasi dan Edukasi; Tanaman Obat

\section{Socialization and Education Of Effective Medicine Plants In Facing COVID-19 Pandemic in Kendari City}

\begin{abstract}
Coronavirus-19 (COVID) has been declared as world pandemic by WHO. This virus is known to have originated in the city of Wuhan, China since December 2019. The President of the Republic of Indonesia has declared the status of this disease to be an Emergency Response stage in March 2020. In order to quickly handle COVID-19, public understanding of preventive measures for public health COVID-19 is needed in Indonesia, especially in several areas of Kendari City, namely Pondambea and Anduonohu villages. The aim of Halu Oleo University Internal Community Service (PKM) to the community was to help the local government increase public awareness to prevent and fight the Covid-19 virus in the form of utilizing nutritious plants that could increase the body's immune system. The form of community service activities was providing counseling, namely the door to door lecture and discussion method and the distribution of free leaflets and masks, the resulting output is an increase in community understanding and skills in cultivating and utilizing nutritious plants so as to achieve increased peace / public health (general public partners).
\end{abstract}

Keywords: COVID-19; Kendari City; Socialization and Education; Medicine plants

Penulis Korespondensi :

Andi Nafisah Tendri Adjeng

Jurusan Farmasi, Fakultas Farmasi, Universitas Halu Oleo, Jl. HEA. Mokodompit, Anduonohu, Kendari-Sulawesi Tenggara, Indonesia, 93232

Email : andinafisah@uho.ac.id

No. Hp : +6282292639162 


\section{PENDAHULUAN}

Pandemi COVID-19 yang terjadi di awal bulan Desember 2019 hingga saat ini membuat sebagian besar masyarakat lebih sadar pentingnya menjaga kesehatan. Beberapa langkah telah dilakukan dalam upaya pencegahan penularan COVID-19 seperti penggunaan masker, jaga jarak, selalu cuci tangan pakai sabun, menggunakan hand sanitizer dan lainlain (Kaddi et al., 2020).

Kota Kendari sebagai ibu kota provinsi menjadi daerah yang tertinggi dengan 1.889 kasus. Angka ini bertambah 58 kasus baru dibandingkan sehari sebelumnya dan menjadikan Kendari masuk dalam zona merah penyebaran COVID-19. Dari jumlah ini, 823 pasien sedang menjalani perawatan (Kumparan.com, 2020).

Dalam upaya pemeliharaan kesehatan untuk selalu menjaga dan meningkatkan imunitas tubuh salah satu caranya dengan mengonsumsi obat herbal, tradisonal dan suplemen kesehatan agar terhindar dari serangan penyakit, termasuk COVID-19. Sosialisasi dan edukasi tentang penggunaan tanaman berkhasiat yang dapat meningkatkan sistem imunitas tubuh dalam upaya peningkatan pemahaman masyarakat dalam memanfaatkan tanaman berkhasiat sehingga dicapai peningkatan ketentraman/kesehatan masyarakat (Pratiwi, 2020).

Indonesia sebagai negara yang kaya akan keanekaragaman hayati berpeluang besar mengembangkan riset obat herbal. Terbukti beberapa herbal dan obat tradisional dapat digunakan sebagai imunomodulator atau peningkat sistem imun seperti kunyit, jahe, temulawak, meniran, jambu biji, sambiloto, echinacea, atau dan memiliki efikasi lainnya seperti antiinflamasi dan antioksidan. Sehingga sangat penting membahas potensi dan peranan obat tradisional sebagai upaya promotif, kuratif, dan preventif dalam menghadapi COVID-19 (Savitri, 2016).

Pemanfaatan beberapa obat tradisional telah terbukti secara empiris dan secara turun menurun dapat memelihara kesehatan tubuh, hal ini pun juga mendapat dukungan dari Badan POM yang berkomitmen mendukung pemanfaatan herbal dan obat tradisional Indonesia untuk dikembangkan menjadi obat herbal, obat tradisional sebagai suplemen kesehatan pencegah COVID-19 (Aditama, 2015).

Pengabdian pada masyarakat merupakan salah satu tridharma perguruan tinggi yang akan dilaksanakan secara terencana oleh Universitas Halu Oleo. Kegiatan pengabdian ini berupa penyuluhan dan sosialisasi yang bertujuan membantu pemerintah setempat dalam meningkatkan kesadaran masyarakat untuk mencegah dan melawan virus COVID-19 dalam bentuk pemanfaatan tanaman berkhasiat obat yang dapat meningkatkan sistem imunitas tubuh.

\section{METODE}

PKM dengan topik "Sosialisasi Dan Edukasi Pemanfaatan Tanaman Berkasiat Obat Sulawesi Tenggara yang Berpotensi Meningkatkan Sistem Imunitas Tubuh dalam Menghadapi Masa Pandemi COVID-19" dalam penyelenggaraannya mematuhi protocol 
kesehatan COVID-19 seperti physical distancing dan social distancing sehingga kegiatan sosialisasi tidak dilakukan dalam skala besar, namun skala kecil seperti sosialisasi rumah warga dan kantor Kelurahan Pondambea dan Anduonohu di Kota Kendari. Penerapan PSBB (Pembatasan Sosial Skala Besar) juga telah diatur dan dihimbau dalam Permenkes RI No 9 tahun 2020 (Kesehatan, 2020). Hal ini dilakukan bertujuan untuk mencegah penyebaran COVID-19 dan memberikan contoh kepada masyarakat pentingnya PSBB selama masa pandemi. Kegiatan Pengabdian Kepada Masyarakat (PKM) kepada masyarakat kota Kendari oleh Internal Universitas Halu Oleo (UHO) dilakukan dengan metode yaitu offline dari rumah ke rumah penduduk (door to door).

Metode yang digunakan dalam kegiatan pengabdian ini adalah ceramah dan tanya jawab kepada warga dengan alat bantu leaflet tanaman berkhasiat obat sebagai sumber informasi. Metode ceramah sering digunakan untuk edukasi dan sosialisasi pada masyarakat umum baik yang berpendidikan tinggi maupun berpendidikan rendah. Pada metode ini penceramah aktif untuk menyampaikan informasi mengenai beberapa tanaman yang ada di Sulawesi Tenggara khususnya Kota Kendari yang berpotensi untuk dijadikan obat dalam meningkatkan daya tahan (imunitas) tubuh. Pendengar ceramah dalam hal ini warga diberi kesempatan untuk menanggapi dan memberikan pertanyaan kepada penceramah atas apa yang telah disampaikan dan yang telah dibaca melalui leaflet. Pemilihan media leaflet karena sebagai media informasi yang sederhana, mudah dibaca dan dapat dibawa dan dibagikan ke teman atau keluarga. Untuk menilai pemahaman dan pengetahuan peserta, dilakukan pretest dan posttest kepada peserta mengenai tanaman yang dapat dijadikan sebagai obat untuk meningkatkan daya tahan tubuh. Tujuannya untuk menilai pemahaman peserta sebelum dan setelah diberikan edukasi dan sosialisasi.

\section{HASIL DAN PEMBAHASAN}

Pengabdian kepada masyarakat ini bertujuan untuk mengetahui cara pemanfaatan tanaman obat keluarga (TOGA) dalam meningkatkan imunitas tubuh manusia agar dapat mencegah Covid-19 di Kota Kendari. Jumlah peserta yang terlibat dalam kegiatan ini adalah 100 orang. Metode yang digunakan adalah sosialisasi kepada masyarakat yakni metode ceramah secara door to door dan mengumpulkan warga di Kelurahan Pondambea dan Kelurahan Anduonohu. Karakteristik warga pada kelurahan Anduonohu dan Pondambea dapat dilihat pada tabel 1 .

Tabel 1. Karakteristik Warga yang mengikuti Kegiatan Pengabdian

\begin{tabular}{llll}
\hline No & Karakteristik & $\begin{array}{l}\text { Kelurahan } \\
\text { Pondambea }\end{array}$ & $\begin{array}{l}\text { Kelurahan } \\
\text { Anduonohu }\end{array}$ \\
\hline 1 & Jenis Kelamin & & \\
& a. Perempuan (orang) & a. 50 & a. 50 \\
& b. Laki-laki (orang) & b. 0 & b. 0 \\
2 & Umur (tahun) & $29-51$ & $26-63$ \\
3 & Pekerjaan & & \\
\hline
\end{tabular}




\begin{tabular}{lll}
\hline a. PNS (orang) & a. 34 & a. 30 \\
b. Ibu Rumah Tangga & b. 16 & b. 20 \\
\hline
\end{tabular}
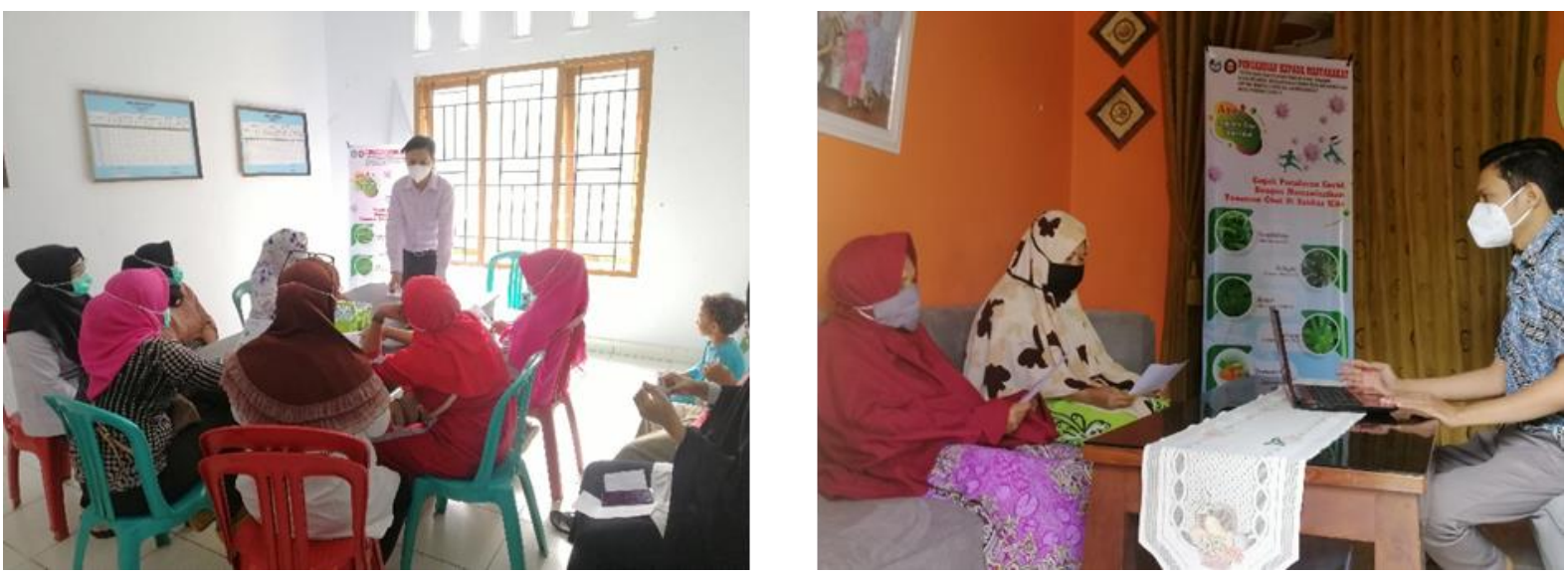

Gambar 1. Sosialisasi di Kelurahan Anduonohu (a) Kantor Kelurahan Anduonohu yang melibatkan ibu-ibu PKK (b) Rumah warga yang dilakukan secara door to door

Sosialisasi dilakukan dengan menjelaskan mengenai tanaman berkhasiat obat yang dapat meningkatkan daya tahan tubuh ditengah pandemi COVID-19 melalui leaflet. Sosialisasi tentang pemanfaatan tanaman obat keluarga (TOGA) dalam

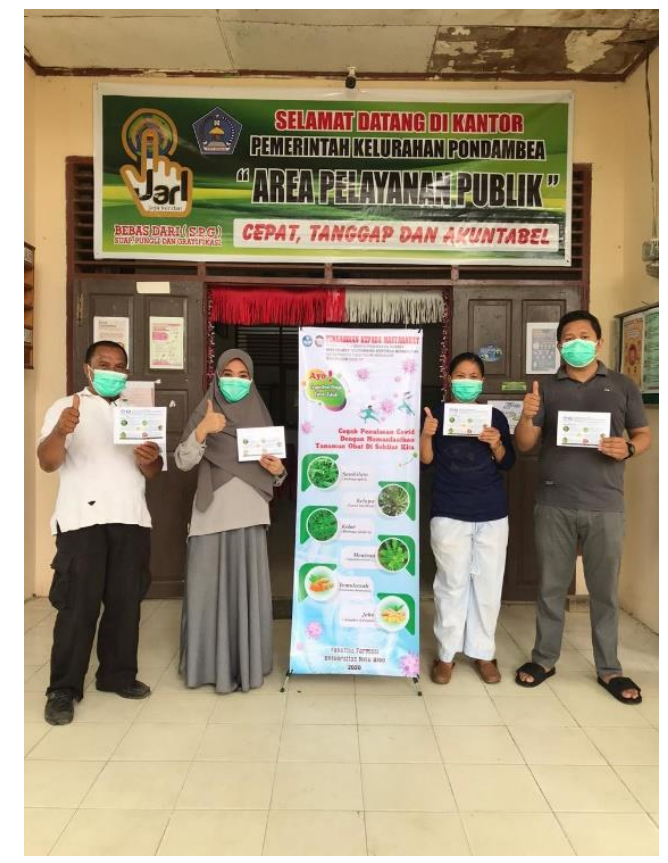

meningkatkan imunitas agar dapat mencegah COVID-19 di Kota Kendari dilaksanakan dengan beberapa tahapan yaitu dengan melakukan pendekatan dan pengenalan tentang pentingnya tanaman berkhasiat obat di lingkungan masyarakat untuk mencegah COVID-19.

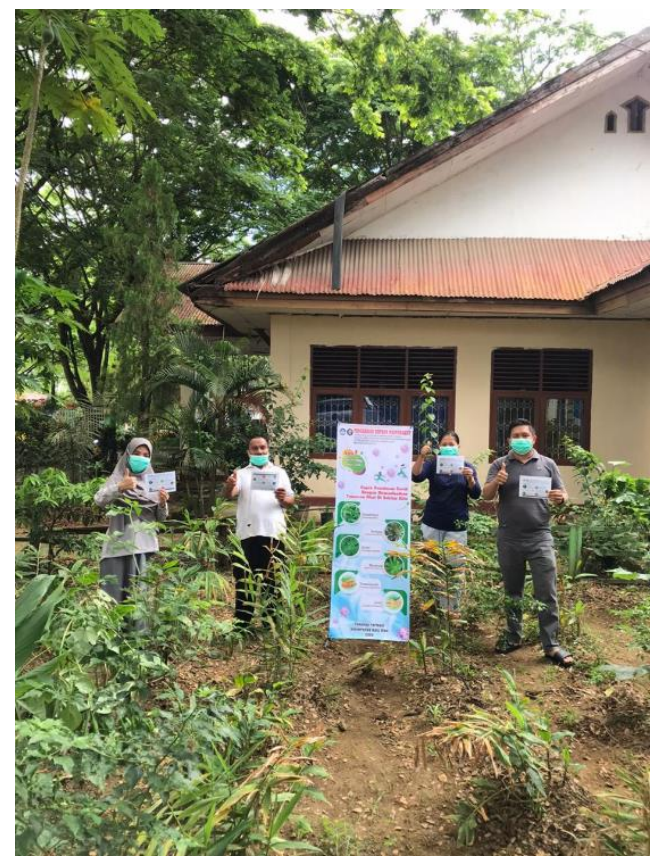

Gambar 3. Sosialisasi di Kelurahan Pondambea (a) Kantor Kelurahan Pondambea (b) Kebun Tanaman Obat kantor Kelurahan 
Obat tradisional pada masa pandemi COVID-19 telah memiliki klaim. Jenis klaim khasiat obat tradisional dalam menghadapi masa pandemi COVID-19 ini lebih kearah sebagai fungsi untuk memelihara dan meningkatkan daya tahan tubuh untuk mencegeh masuknya virus corona. Obat tradisional tidak hanya dibuktikan secara turun temurun tetaapi juga harus dibuktikan melalui penelitian ilmiah yaitu secara skala laboratorium (uji in vitro) dan uji ke hewan coba (uji in vivo).

Beberapa jenis tanaman yang disosialisasikan kepada warga kota dibeberapa daerah kota Kendari antara lain:

a. Tanaman Sambiloto (Andrographis paniculata Nees.)

Aktivitas immunomodulator tanaman Andrographis paniculata Nees dapat sebagai terapi alternatif dalam meningkatkan sistem imunitas tubuh. Sambiloto merupakan tanaman asli Indonesia yang mengandung deoxyandrographolide, andrographolide, 14-deoxy-11, neoandrographolide, $12-$ didehydroandrographolide, homoandrographolide, diterpenoid dan flavonoid. Sambiloto dapat digunakan sebagai immunostimulator yang meningkatkan respon imun saat kekebalan tubuh menurun, dan juga bisa menjadi imunosupresor yang dapat menurunkan respon kekebalan tubuh saat sistem kekebalan tubuh meningkat melebihi kondisi tubuh normal. (Alkandahri et al., 2018).

b. Virgin Coconut Oil (VCO)
Minyak kelapa murni Virgin Coconut Oil (VCO) merupakan minyak kelapa yang diperoleh yaitu dengan penambahan enzim, pancingan, dan sentrifugasi tanpa melibatkan proses pemanasan. Minyak kelapa banyak mengandung asam lemak jenuh rantai sedang, yang berkhasiat sebagai herbal alternative untuk pengobatan dan pencegahan penyakit degeneratif maupun penyakit yang disebabkan mikroorganisme. Kandungan vco yang utama adalah asam lemak jenuh rantai sedang yaitu: asam laurat, asam kaprilat, asam miristrat, asam palmirat yang mudah dicerna oleh tubuh menjadi energi (Dewi \& Aryadi, 2010).

VCO mampu mengatasi berbagai penyakit antara lain Diabetes militus, obesitas,kolesterol, jantung, osteoporosis; juga mampu membasmi penyakit yang disebabkan oleh mikroba dan jamur seperti: HIV, hepatitis, herpes, influenza, cytomegalovirus, streptococcus, staphylococcus, bakteri gram negatif dan candida penyebab keputihan (Sutarmi, 2006).

c. Daun kelor (Moringa oleifera Lam)

Daun kelor (Moringa oleifera Lam) memiliki kandungan saponin dan flavonoid lebih tinggi. Flavonoid pada daun kelor memiliki peran sebagai antioksidan dan mampu menghentikan reaksi berantai radikal (Toripah, 2014). Hasil penelitian lain menunjukkan pemberian ekstrak daun kelor selain meningkatkan jumlah sel $\mathrm{T}$ 
CD4+ juga terbukti dapat meningkatkan jumlah relatif sel $\mathrm{T}$ CD8+ serta daun kelor memiliki peran sebagai imunostimulan karena dapat meningkatkan aktivitas makrofag (Biswas et al., 2012).

d. Meniran (Phyllantus niruri L.)

Meniran adalah herba yang berasal dari genus Phyllanthus dengan nama ilmiah Phylanthus niruri Linn. Tanaman ini juga berkhasiat sebagai imunodumudulator, hal ini terbukti telah dipatenkannya meniran sebagai obat Stimuno® (Sulaksana \& Jayusman, 2004).

Ekstrak meniran secara oral bisa mempengaruhi faedah dan kegiatan kompenen sistem imun. Kandungan senyawa aktif biokimia dalam meniran, yang dimanfaatkan yakni flavonoid-nya dimana dapat menambah sistem kekebalan tubuh. Dari sekian banyak hasil penelitian diduga bahwa ekstrak meniran dapat dipakai sebagai terapi ajuvan pada penyakit infeksi akut dan kronis seperti TBC, hepatitis, ISPA, herpes zoster dsb (Kardinan \& Kusuma, 2004).

e. Jahe (Zingiber officinale)

$$
\text { Jahe (Zingiber officinale) }
$$
memiliki kandungan senyawa kimia aktif yang berfungsi preventif dan kuratif. Dari segi nutrisi, jahe mengandung kalori, karbohidrat, serat, protein, sodium, besi, potasium, magnesium, fosfor, zeng, folat, vitamin $\mathrm{C}$, vitamin $\mathrm{B} 6$, vitamin A, riboflavin dan niacin. Beberapa senyawa kimia aktif dalam rimpang jahe yang berefek farmakologis terhadap kesehatan, antara lain: minyak atsiri dengan kandungan zat aktif zingiberin, kamfena, lemonin, borneol, shogaol,sineol, fellandren, zingiberol, gingerol,dan zingeron. Sebagai bahan obat tradisional, jahe memiliki khasiat untuk mencegah dan mengobati berbagai penyakit,seperti: impoten, batuk, pegal-pegal, kepala pusing, rematik, sakit pinggang, masuk angin, bronchitis, nyeri lambung, nyeri otot, vertigo, mualsaat hamil, osteoarthritis, gangguan sistem pencernaan, rasa sakit saat menstruasi, kadar kolesterol jahat dan trigliserida darah tinggi, kanker,sakit jantung, fungsi otak terganggu, Alzheimer, penyakit infeksi, asma, produksi air susu ibu terganggu, gairah seksual rendah, dan stamina tubuh rendah (Aryanta, 2019).

f. Temulawak (Curcuma xanthorriza Roxb).

\begin{tabular}{ll}
\multicolumn{3}{c}{ Mengkonsumsi OMAI (Obat } \\
Modern Asli Indonesia) atau \\
biasa kita kenal dengan obat
\end{tabular}
tradisional ini adalah salah satu tindakan yang dapat dilakukan untuk penanganan COVID-19 saat ini. Salah satu OMAI atau obat tradisional yang terdapat di Indonesia yang dapat digunakan untuk meningkatkan sistem imun yaitu temulawak (Curcuma Xanthorrhiza) (Izazi \& Kusuma, 2020). Manfaat yang lain dari temulawak (Curcuma Xanthorrhiza) adalah untuk menyegarkan tubuh, memperlancar metabolisme, menyehatkan fungsi hati, 
menambah nafsu makan, sebagai imunomodulator dan hepatoprotektor. Serta temulawak (Curcuma Xanthorrhiza) juga digunakan untuk meningkatkan daya tahan dan stamina tubuh. Studi menunjukkan bahwa ekstrak temulawak (Curcuma Xanthorrhiza) dapat menginduksi aktivitas sistem imun (Kim et al., 2007), terdapat penelitian melaporkan pemberian temulawak (Curcuma Xanthorrhiza) dapat meningkatkan respons imun pada ayam yang diberi vaksin flu burung (Kosim et al., 2007). Penggunaan temulawak (Curcuma
Xanthorrhiza) dalam pengobatan tradisional banyak digunakan dalam pengobatan gangguan pencernaan, sakit kuning, keputihan, meningkatkan daya tahan tubuh serta menjaga kesehatan (Kuntorini, 2018).

Kegiatan evaluasi yang dilakukan untuk menilai pengetahuan dan pemahaman masyarakat mengenai tanaman berkhasiat obat yang dapat digunakan untuk meningkatkan imunitas tubuh dilakukan dengan ujian tertulis berupa pretest dan posttest. Hasil yang diperoleh dapat dilihat pada gambar

3.

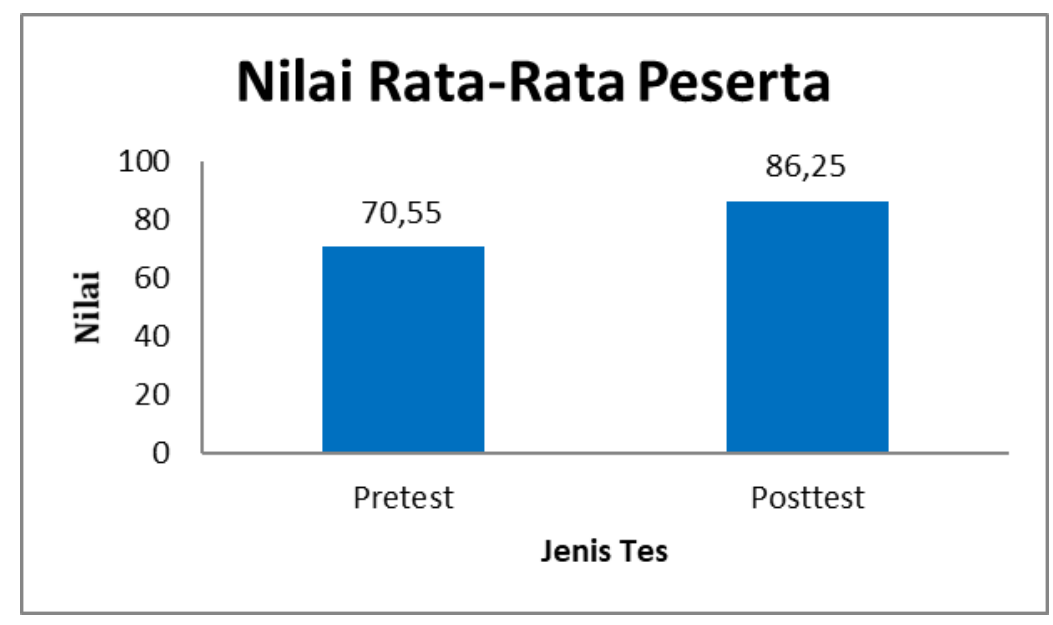

Gambar 3. Nilai Pretest dan Posttest Pengetahuan Warga Kelurahan Pondambea dan Kelurahan Anduonohu tentang Pemanfaatan Tanaman Obat untuk meningkatkan imunitas tubuh

Gambar 3 menunjukan nilai ratarata peserta dari hasil pretest dan posttest tentang pemanfaatan tanaman obat yang dapat digunakan untuk meningkatkan daya tahan tubuh. Hasil yang diperoleh terjadi peningkatan sebelum dan setelah diberikan edukasi dan sosialisasi. Hal ini menunjukan adanya peningkatan pengetahuan warga dalam mengenali dan memanfaatkan tanaman yang berkhasiat obat untuk meningkatkan daya tahan (imunitas) tubuh.

\section{KESIMPULAN}

Berdasarkan hasil kegiatan Pengabdian Kepada Masyarakat yang telah dilakukan pada warga Kelurahan Pondambea dan Kelurahan Anduonohu Kota Kendari dapat disimpulkan bahwa 
kegiatan sosialisasi dan edukasi ini dapat meningkatkan pengetahuan dan keterampilan warga dalam mengenali, memanfaatkan dan mengolah tanaman yang berkhasiat obat untuk meningkatkan daya tahan (imunitas) tubuh selama masa Pandemi COVID-19. Kegiatan edukasi dan sosialisasi ini dapat dilanjutkan dan dilakukan peserta baik langsung maupun tidak langsung untuk memonitor keberlanjutan kegiatan ini.

\section{UCAPAN TERIMA KASIH}

Ucapan terima kasih diucapkan kepada Universitas Halu Oleo yang telah memberikan pendanaan untuk kegiatan Pengabdian Kepada Masyarakat tahun 2020.

\section{DAFTAR PUSTAKA}

Aditama, T. Y. (2015). Jamu \& kesehatan. Lembaga Penerbit Badan Penelitian Dan Pengembangan Kesehatan (LPB), Jakarta, Indonesia.

Alkandahri, M. Y., Subarnas, A., \& Berbudi, A. (2018). Aktivitas Immunomodulator Tanaman Sambiloto (Andrographis paniculata Nees). Farmaka, 16(3), 16-21.

Aryanta, I. W. R. (2019). Manfaat Jahe Untuk Kesehatan. Widya Kesehatan, 1(2), 39-43.

Biswas, S. K., Chowdhury, A., Das, J., Roy, A., \& Hosen, S. M. Z. (2012). Pharmacological potentials of Moringa oleifera Lam.: a review. International Journal of Pharmaceutical Sciences and Research, 3(2), 305.

Dewi, S. S., \& Aryadi, T. (2010). Efektifitas Virgin Coconut Oil (VCO) terhadap Kandidiasis Secara Invitro. PROSIDING SEMINAR NASIONAL \& INTERNASIONAL.

Izazi, F., \& Kusuma, A. (2020). Hasil Responden Pengetahuan Masyarakat Terhadap Cara Pengolahan Temulawak (Curcuma Xanthorrhiza) dan Kencur (Kaemferia galanga) Sebagai Peningkatan Imunitas Selama COVID-19 dengan Menggunakan Kedekatan Konsep Program Leximancer.
Journal of Pharmacy and Science, 5(2), 9397.

Kaddi, S. M., Lestari, P., \& Adrian, D. (2020). Komunikasi Keluarga Dalam Pencegahan Coronavirus Disease 2019. Jurnal Ilmu Komunikasi, 18(1), 63-74.

Kardinan, I. A., \& Kusuma, F. R. (2004). Meniran penambah daya tahan tubuh alami. AgroMedia.

Kesehatan, M. (2020). Permenkes No. 9 Tahun 2020 tentang Pedoman PSBB dalam Rangka Percepatan Penanganan Covid-19. In Www.Covid-19.Go.Id (pp. 1-28).

Kim, A.-J., Kim, Y.-O., Shim, J.-S., \& Hwang, J.-K. (2007). Immunostimulating activity of crude polysaccharide extract isolated from Curcuma xanthorrhiza Roxb. Bioscience, Biotechnology, and Biochemistry, 705080406.

Kosim, L., Priosoeryanto, B. P., \& Purwakusumah, E. D. (2007). Potensi Temulawak Testandar Untuk Menanggulangi Flu Burung.[Laporan penelitian]. Bogor (ID): Pusat Studi Biofarmaka, Institut Pertanian Bogor.

Kumparan.com. (2020). Update Corona di Sultra: Kendari Catatkan Kasus Tertinggi dan Masuk Zona Merah. https://kumparan.com/kendarinesia/upd ate-corona-di-sultra-kendari-catatkankasus-tertinggi-dan-masuk-zona-merah1uNRkJXDd9V/full

Kuntorini, E. M. (2018). Botani ekonomi suku Zingiberaceae sebagai obat tradisional oleh masyarakat di Kotamadya Banjarbaru. Bioscientiae, 2(1).

Pratiwi, A. R. (2020). Pangan Untuk Sistem Imun. SCU Knowledge Media.

Savitri, A. (2016). Tanaman Ajaib! Basi Penyakit dengan TOGA (Tanaman Obat Keluarga). Bibit Publisher.

Sulaksana, J., \& Jayusman, D. I. (2004). Meniran, Budidaya dan Pemanfaatan Untuk Obat. Jakarta: Penebar Swadaya.

Sutarmi, R. H. (2006). Taklukkan penyakit dengan VCO. Ed, 5, 5-24.

Toripah, S. S. (2014). Aktivitas Antioksidan Dan Kandungan Total Fenolik Ekstrak Daun Kelor (Moringa oleifera LAM). Pharmacon, $3(4)$. 